\title{
BANK CREDIT AND TRADE CREDIT AFTER THE FINANCIAL CRISIS: EVIDENCE FROM RURAL GALICIA
}

\author{
David PEÓN ${ }^{1} 1^{*}$, Xulia GUNTÍN ${ }^{2}$ \\ ${ }^{1}$ Department of Business, University of A Coruña, Campus Elviña s/n, 15071 A Coruña, Spain \\ ${ }^{2}$ Department of Quantitative Economics, University of Santiago de Compostela, \\ 15782 S. Compostela, Spain
}

Received 30 July 2020; accepted 04 December 2020

\begin{abstract}
Access to external finance is a key challenge for the creation, survival and growth of SMEs. This article delves into the "weak funding" handicap of rural small firms (SEs): the access to bank financing and the substitutive role of trade credit for entrepreneurs in rural areas when they faced bank credit constraints. Considering SEs in Galicia (Spain), a paradigmatic case in Europe of rural areas in demographic decline with a strong impact of the Spanish sovereign and banking crisis of 2008-2012. There's evidence of firms in rural areas facing a differential negative flow of bank credit during the financial crisis, especially in the manufacturing and construction sectors, that dissipated afterwards. Then, using a panel data approach that considers the determinants of trade credit, the complementary and substitutive hypotheses are tested to estimate the impact of bank credit restrictions over trade credit.
\end{abstract}

Keywords: trade credit, bank credit constraints, rural development, SME, SE, entrepreneur.

JEL Classification: R51, G32, G21, L26.

\section{Introduction}

Half the World's population lives in cities today. In Europe, the increasing urbanisation is also a reality, but rural Europe is yet home to more than half of the population and covers more than three quarters of the territory. There is a growing view that a sustainable urban development depends on the prosperity of rural areas as well. However, growth prospects are sluggish in many rural regions, for demographic reasons, with depopulation and ageing threatening to marginalize them. Fostering entrepreneurship and business development of micro, small (SEs) and medium enterprises (SMEs) is a key target in the Europe2020 strategy, but SEs in rural areas face drawbacks such as dealing with lower demand and less favourable ecosystems, worse infrastructure and administrative burdens, weaker innovation abilities, and lack of access to private and public capital (Erjavec \& Rickson, 2016).

*Corresponding author. E-mail: david.peon@udc.es 
The motivation of this article is to delve into the "weak funding" handicap of rural firms. According to the OECD, access to finance is a significant challenge for the creation, survival and growth of SMEs (OECD, 2012). For rural firms, weak access to capital is a major barrier (Civelek et al., 2019). Bank credit constraints limit their growth, and financing costs are higher for "businesses located in remote and/or rural areas, potentially excluding them from any sources of formal external financing" (OECD, 2018, p. 8). The topic is gaining momentum. Several authors show that SMEs suffered from a significant credit crunch during the recent financial crisis (Carbó-Valverde et al., 2016). Bank lending to SMEs was reduced significantly after the financial crisis: from 2008 to 2011, by $47 \%$ in the EU, varying from $21 \%$ in Italy to $82 \%$ in Ireland (McGuinness \& Hogan, 2016).

In this context, however, the access to financing by SEs in rural areas of Europe has been barely studied. Some alternatives to bank credit constraints, such as retained earnings or government subsidies, were hardly available during the crisis (OECD, 2018; Instituto de Crédito Oficial [ICO], 2014, 2015) ${ }^{1}$. Trade credit might have been the only bootstrap financing alternative for many of these firms. The substitutive versus complementary role of trade credit has been covered in the literature, including Spanish firms (e.g., Martínez-Sola et al., 2017). Nonetheless, this research contributes in terms of the novelty of the contextual setting: a differential substitutive role of trade credit for rural SEs was never tested. Recently, Del Gaudio et al. (2018) review the state of arts and observe a discrepancy of results, driven by the lending infrastructure of the country. We delve further into the territorial dimension of analysis.

This article analyses SEs in Galicia (Spain), an interesting case study for two reasons: being a paradigmatic case in Europe of rural areas in demographic decline, and the impact of the Spanish sovereign and banking crisis there. The structure is as follows. Section 1 reviews the literature on bank credit constraints and trade credit. In Section 2, variables and hypotheses are defined. Section 3 introduces the case study, describes the dataset, and provides a descriptive analysis of bank credit and trade credit over the period of analysis. In Section 4 , a panel data analysis is performed for the determinants of trade credit. The results are then discussed, followed by a final Section with a set of conclusions. Additional results are provided in a Supplementary Material (SM).

\section{State of the art}

Academics and practitioners identify three drawbacks for firms in rural areas. First, weak capacities, referred to those of the managers and firms (Erjavec \& Rickson, 2016); second, weak infrastructure, including barriers such as the digital divide, limited access to research, and administrative burdens (European Commision, 2016); third, weak funding, referred to restricted access to private and public capital. This research deals with the latter topic.

The conceptual framework combines a resource-based view theory of the firm, credit rationing by financial institutions, and the substitutive role of trade credit in face of bank

\footnotetext{
1 To illustrate, the Spanish Credit Institute (ICO), the largest public finance agency, reports a sharp contraction of business credit lines, from 2010 to 2012, of $-41.3 \%$. Credit recovered afterwards, with a maximum in year 2014, once the sovereign crisis was over (ICO, 2015, p. 16). More than $60 \%$ of financing granted in year 2014 was to micro enterprises and self-employed. The credit crunch peaked in the second quarter of 2013 (ICO, 2014, p. 11).
} 
credit restrictions. There is extensive literature on weak funding by rural SEs in emerging countries (de Castro \& Teixeira, 2012). For Western countries, however, there is less research. Examples are Besser and Miller (2013) on U.S. rural entrepreneurs, Civelek et al. (2019) on Slovak weak funding bias compared to Czech Republic, and Khanal and Omobitan (2020) on factors influencing credit constraints of farms in the U.S.

In face of bank credit restrictions, trade credit may act as a substitute or a complement to bank financing:

- According to the substitution hypothesis, if a firm faces bank credit constraints, trade credit plays a means of funding of last resort. Trade credit is often used as a substitute by small firms, who tend to face credit rationing more frequently.

- The complementary hypothesis may obey to two reasons. At the individual level, if credit receivables exceed the maturity period of credit payables, the firm must use bank loans and short-term credit to meet its working capital requirements. At the industry level, firms with easier access to loans can facilitate the expansion of trade credit in the industry. Thus, it may be optimal for banks to lend to efficient firms at monitoring customers, which then refinance others through trade credit.

Psillaki and Eleftheriou (2015) obtain evidence of a flight-to-quality hypothesis: bank credit flows away from borrowers facing higher costs to larger, higher-grade firms. Palacín et al. (2019) find that the substitutive relation between trade credit and bank credit works better in countries with more efficient banks. However, this was rarely studied in relation to the rural setting in which firms operate. In advanced economies, results are inconclusive. Gustafson (2005) finds that rural U.S. SMEs with greater use of credit management systems act as lenders in trade credit relationships. Niskanen and Niskanen (2006) find that firms in urban areas of Finland offer and use more trade credit than their rural counterparts. In Italy, Cassia and Vismara (2009) find that companies tend to finance via suppliers when bank credit conditions are not good, but Deloof and La Rocca (2014) obtain opposite results. Deloof et al. (2019) find that branch density in the region has a significant negative effect on the use of trade credit. An emerging line of research links the new financial technologies (Fintech) to the financial inclusion of rural regions. Thus, Friedline et al. (2020) analyse whether Fintech help to expand access to financial services in rural areas of the U.S. However, most of this research is again oriented to emerging economies - e.g., Kohardinata et al. (2020) for Indonesia; Siddiqui and Siddiqui (2020), in India.

\section{Variables and hypothesis development}

Different measures of bank and trade credit are used. The credit a firm gets from financial institutions is measured through variable flow of short-term debt repayable within one year $(\triangle \mathrm{STD})$. Trade credit may be measured through the accounts receivable-to-sales (RECS), which measures the trade credit offered to customers, or through accounts payable-to-assets (PAYAS), measuring the importance of trade credit in the financing of the firm.

The first hypothesis is whether firms operating in rural areas faced a differential bank credit constraint during the financial crisis. It is defined akin to Psillaki and Eleftheriou (2015) test for a differential performance of small versus large companies: 
H1: After the banking and sovereign debt crisis, loanable funds shift back to credit constrained firms in rural areas.

That is, if firms in rural areas had poorer access to bank credit during the worse years of the bank and sovereign debt crisis in Spain (years 2008 to 2012), one should observe how credit started to flow to these firms from year 2013 onwards.

A second hypothesis seeks to describe the effects of the financial crisis over trade credit as well. The ultimate goal is to test whether trade credit acted as a substitute for financially restricted companies in rural areas; however, we firstly observe the impact of the crisis on trade credit. Following McGuinness and Hogan (2016), the hypothesis is defined as:

H2: Net trade credit reduced during the banking and sovereign debt crisis, particularly for firms in rural areas.

Following the liquidity and credit theory (Schwartz, 1974), firms with better access to bank credit offer trade credit to their customers (RECS) for their own profit. However, in a context of bank credit shortage, if trade credit acts as a substitute to bank credit, more firms would increase accounts payable (PAYAS), and reduce the financing they offer to their customers (RECS). Thus, net trade credit (NTCS), measured as the ratio of accounts receivable minus payables scaled by sales, is used to test $\mathrm{H} 2$.

$\mathrm{H} 1$ and $\mathrm{H} 2$ are intended for descriptive purposes. A causal interpretation requires the formulation of alternative hypotheses that follow the literature on the determinants of capital structure and trade credit, respectively. The impact of the rural nature of firms over the access to bank credit is tested with hypothesis $\mathrm{H} 3$ :

H3: The flow in bank credit during the crisis was negatively related to the rural location of the firm.

To test H3, the flow of short-term debt repayable within one year $(\Delta \mathrm{STD})$ is used as dependent variable, while the main explanatory variable is the rural nature of the firm (REMOTE). Control variables follow the conceptual framework of determinants of capital structure. Borrowing from Psillaki and Eleftheriou (2015), debt borrowing depends on asset structure (FTA) measured by the ratio of fixed tangible to total assets, the profitability (measured by ROA) and the solvency of the firm (SR), measured by the ratio of after-tax income minus depreciation to total debt, as a measure of business risk.

The effect of these control variables over $\triangle$ STD depends on the theory followed. Thus, asset tangibility (FTA) would be positively related to debt, since asymmetric information and agency costs of debt induce lenders to require collateral (Scott, 1977), and funding costs are normally smaller for firms investing in PP\&E than in intangible assets. However, a negative relationship may exist under an underinvestment or debt overhang situation, where firms with a stable source of internal financing are reluctant to seek external financing, overlooking profitable investments if they benefit only creditors (Psillaki \& Eleftheriou, 2015). Since most of the SMEs are of low asset base, FTA would have a negative relation to flow of capital, supporting a negative relationship of FTA and debt.

The relationship between profitability (ROA) and (short-term) debt would be negative according to the pecking-order theory (POT) because, under informational asymmetries, profitable firms would prefer internal to external financing, and risky debt to new equity (Psillaki \& Daskalakis, 2009). However, a positive relationship appears under the trade-off 
theory, due to the tax shield benefit of debt. This result depends on the existence of fiscal incentives supporting debt acquisition as a growth strategy for SEs. Finally, POT also predicts a positive relationship between solvency (SR) and leverage, since firms with higher business risk try to retain cash to avoid underinvestment. Contrariwise, a negative relationship is expected under an agency costs perspective (Harris \& Raviv, 1990).

Finally, the role of trade credit as a substitute or complement to bank financing is tested separately for firms that had access to credit and for those that were restricted. Hypothesis $\mathrm{H} 4 \mathrm{a}$ and $\mathrm{H} 4 \mathrm{~b}$ are defined as follows:

H4a: Under the complementary hypothesis, firms with a positive flow in bank credit offered more trade credit to their customers.

H4b: Under the substitution hypothesis, firms with a negative flow in bank credit more trade credit payables as a source of financing.

Following the literature of determinants of trade credit, the dependent variable for $\mathrm{H} 4 \mathrm{a}$ is the ratio of accounts receivable to sales (RECS), and for $\mathrm{H} 4 \mathrm{~b}$, the ratio of accounts payable to assets (PAYAS). Explanatory variables are flow of short terms debt $(\Delta \mathrm{STD})$ and the rural nature of the firm (REMOTE). Control variables are of three types: creditworthiness, commercial and operative motives, and financial motives.

Having access to alternative sources of financing explains why firms may lend to their customers or borrow from their suppliers. For SEs, the main sources are internal financing and bank credit. Hence, the ratio of internal financing (net profit plus depreciation expenses) scaled by sales (INTFINS) is used to explain PAYAS, and scaled by assets (INTFINA) to explain RECS - to avoid multicollineality of INTFINS. A positive relationship between INTFINA and RECS is expected, and, following POT, a negative relationship between INTFINS and PAYAS. Access to bank credit is measured with $\triangle$ STD. In addition, we control for firms' ability to get external financing with common proxies such as firms' age (AGE) and size (logASSETS).

Commercial and operative motives follow three theories. First, price discrimination theory (Petersen \& Rajan, 1997) suggests that trade credit allows firms to charge a higher price to less solvent customers. Thus, RECS would be positively related to higher operating margins (MARG), defined as the ratio of operating income to sales revenues. A negative relationship between MARG and PAYAS is expected, since firms that do not benefit from early payment discounts see their margin reduced. Second, if asymmetries of information exist between buyers and sellers, trade credit allow suppliers to guarantee the quality of their products (Smith, 1987) and obtain information about their customers' solvency. Hence, asset turnover (TURN), defined as sales over (assets - accounts receivable), would be negatively related to RECS, since firms with lower sales turnover produce higher quality goods - quality controls extend the production cycle. TURN is not included to estimate PAYAS. Third, operative motives are based on obtaining higher levels of efficiency and cost reduction. On one hand, firms' size (ASSETS) are positively related to RECS, since larger firms offer more trade credit due to economies of scale. On the other hand, trade credit gives flexibility to respond to variations in demand (Baños-Caballero et al., 2016): the annual sales growth multiplied by two dummies is used, whether growth was positive (PGROWTH) or negative (NGROWTH). The impact over RECS may be positive or negative, depending on whether the company offers better conditions to their customers and sales follow, or they use trade 
credit as a marketing mechanism to improve weak sales (Niskanen \& Niskanen, 2006). For PAYAS, a positive relationship with PGROWTH (or NGROWTH) is expected because the higher growth, the more investment opportunities, and companies use trade credit to finance current assets.

Financial motives to offer trade credit (RECS) are based on information asymmetries, now on the banks' side: suppliers have a comparative advantage to monitorize their customers. Hence, the liquidity and credit theory predicts that short-term finance to sales (STFINS), defined as the ratio of current liabilities to sales revenues, will be positively related to RECS. Financial motives to use trade credit (PAYAS) may be of three types. First, the ratio of short term debts (current liabilities minus trade payables) to assets (STDA), with a negative relationship if a substitution effect between short-term credit and trade credit exists. Second, for asset maturity purposes (working capital management), firms must balance the maturity of short-term liabilities with the liquidity of their assets. Here the ratio of current assets to total assets (CURRAS), with a positive expected relationship is used. Third, a substitution effect might also exist with long-term debts as well, and so leverage (LEVER) is included, measured as the ratio of long-term liabilities to capital, with a negative expected relationship.

\section{Case of study and descriptive analysis}

The case of study is introduced before addressing the empirical testing of the hypotheses. In the analysis of bank credit constraints by SEs operating in rural areas, Galicia - a NUTS level 2 region in the North-West of the Iberian Peninsula - is a case of great interest, for two reasons: demographic and financial.

First, Galicia is a paradigmatic aged region in Europe in demographic decline. With an extension of 30,000 square $\mathrm{km}$. and 2.75 million inhabitants, the average population age is four years higher than that of Spaniards and Europeans, and the fertility rate among the lowest in the world (1.07 children per woman), which contributes to a negative vegetative balance ( -3.03 per thousand). Hence, it has historically lagged Spain in terms of population and GDP growth. The dynamics of its rural areas is worse. Almost $70 \%$ of the population

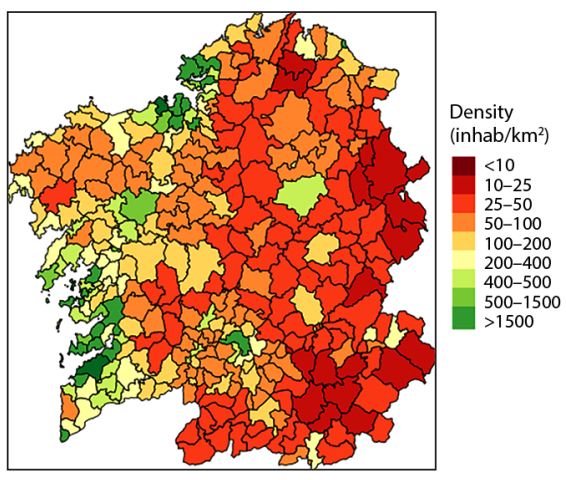

Urban-rural typology of municipalities

Figure 1. Distribution of Galician population. Density by municipalities 2011 and urban-rural typology 
lives in $15 \%$ of the territory, the Eixo Atlántico, a line that goes from North to the Portuguese border in the South and includes the largest urban centres - see Figure 1.

Second, for financial reasons, the impact of the sovereign and banking crises. The banking sector in Spain experienced a complete restructuring process: the more than fifty banks and saving banks before 2009 were transformed into ten groups holding $80 \%$ of the assets, and savings banks disappeared. Credit decreased substantially since then (Figure 2). In this context, Spanish SMEs - 99.8\% of firms offering 74\% of total employment in 2011 - were severely affected. Galician economy suffered the bankruptcy of some of the largest industrial firms and the disappearance of all its local financial institutions. Branches were reduced by more than a third, leaving $40 \%$ of municipalities with only one branch or none.

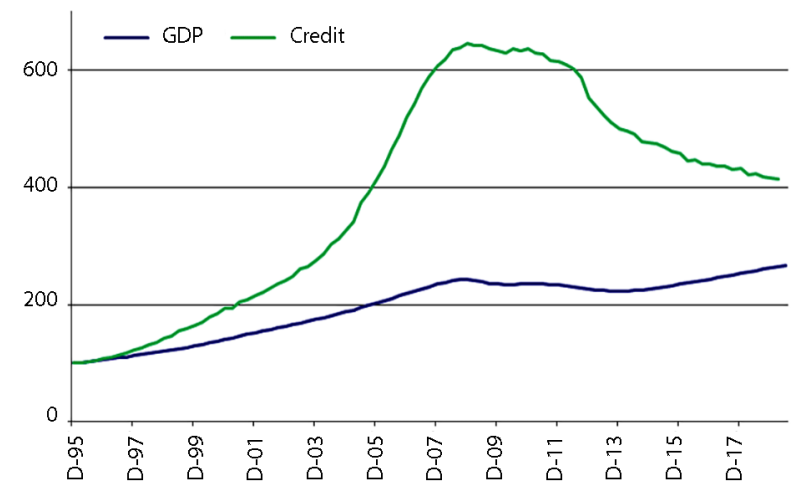

Figure 2. Credit to households and firms. Spain, 1996-2017 (1996 base = 100)

To target a dataset of SEs that is representative of the Galician economy, we start with the sectoral distribution. Following the Galician Statistics Institute (IGE) classification of municipalities by its degree of urbanization, based on Eurostat's DEGURBA standards, 242 of them are rural (of a total of 315 in year 2016). That year, the largest sectors by number of firms were agriculture, forestry and fishing sectors (11.2\%), food and beverages (3.9\%), construction and specialized construction (18.2\%), wholesale trade (9.9\%), retail trade $(9.2 \%)$, and hotels and restaurants (6.9\%). We focus on the most relevant: agrifood (NACE 1, 2, 3, 10,11 ), manufacturing of wood and metal (NACE 16, 25), construction of buildings (NACE 41), wholesale trade (NACE 46), and the retail trade sector (NACE 47).

SEs are defined following the criteria by the EU Recommendation 2003/361/EC: firms are classified as small (micro) if staff headcount is less than 50 (10) and either turnover or balance sheet total is less than 10 (2) million. The database consists of stand-alone SEs in Galicia in the sectors above mentioned. Medium-sized firms (less than 250 employees, and either turnover or assets of less than 50 or 43 million euros) are not considered. Companies are classified as set either in urban, intermediate, or rural areas, following DEGURBA. Within rural firms, when they operate in rural (low) municipalities, they are classified as REMOTE. Then, the financial statements from 2008 to 2015 of all active and independent SEs with complete reports all years are retrieved from SABI Bureau van Dijk database. Cases with missing values for some variables or with errors in the accounting data are excluded. Thus, we require equity, revenues, assets, current assets, fixed assets, liabilities, and current liabilities 
to be positive. 2,145 SEs are obtained, 372 from rural areas. Table 1 provides the number of observations, balanced in the territorial and sectoral dimensions.

Table 1. Territorial and sectoral distribution of the sample observations

\begin{tabular}{|l|c|c|c|}
\hline Urbanisation & Freq. & Percent & Cum. \\
\hline Urban & 5,192 & 30.26 & 30.26 \\
\hline Intermediate & 6,584 & 38.37 & 68.62 \\
\hline Rural & 5,384 & 31.38 & 100 \\
\hline of which & & & \\
\hline Remote & 2,976 & 17.34 & \\
\hline Total & 17,160 & 100 & \\
\hline
\end{tabular}

\begin{tabular}{|l|c|c|c|}
\hline \multicolumn{1}{|c|}{ Sector } & Freq. & Percent & Cum. \\
\hline agrifood & 1,864 & 10.86 & 10.86 \\
\hline manufacture & 2,152 & 12.54 & 23.4 \\
\hline construction & 2,160 & 12.59 & 35.99 \\
\hline wholesale & 6,312 & 36.78 & 72.77 \\
\hline retail & 4,672 & 27.23 & 100 \\
\hline Total & 17,160 & 100 & \\
\hline
\end{tabular}

The set of variables are provided in Table A1 in the SM. Correlation analysis excludes MARG from subsequent analysis, since its effect over RECS and PAYAS is explained by INTFINA and INTFINS, respectively. Total sales revenues (REVEN) was included only for descriptive purposes. Since flow variables miss the first year of data, the descriptive statistics exclude year 2008. In addition, all financial variables are winsorised at the $1 \%$ and $99 \%$ levels - to mitigate the effect of extreme outliers. The dataset considers the refined number of firms and eight annual observations per company.

A descriptive analysis follows. First, the flow of bank credit $(\triangle \mathrm{STD})$ and differences in trade credit policies (both RECS and PAYAS) for rural firms versus urban and intermediate areas, between the crisis (years 2009-2012, denoted P1) and post-crisis (2013-2015, P2). Figure 3 shows that both the credit restriction during the crisis and the back-to-normal performance afterwards were stronger for remote rural firms. However, there are no differences overall in terms of trade receivables, either temporal or territorial, and the average use of supplier financing is higher during the crisis, but by firms of any kind.

Any distinctive behaviour may be due to differences across sectors. Indeed, as Table 2 shows, weights by sector are quite different for rural municipalities, with less companies operating in trade sectors - wholesale and retail. Moreover, firms of these two sectors tend to use more supplier financing, and the retail sector offers little credit (RECS amounts only to $11.79 \%$ ). Hence, for better interpretation, we compare the flow of bank borrowing, during and after the crisis, by sector in urban vs. remote rural settings (see Figure 4).

Table 2. Number of observations and average trade credit figures by economic sector

\begin{tabular}{|l|c|c|c|c|c|c|}
\hline & agrifood & manufacture & construction & wholesale & retail & Total \\
\hline non_remote & 1,211 & 1,470 & 1,456 & 4,718 & 3,556 & 12,411 \\
\hline$\%$ & 9.76 & 11.84 & 11.73 & 38.01 & 28.65 & 100 \\
\hline remote & 420 & 413 & 434 & 805 & 532 & 2,604 \\
\hline$\%$ & 16.13 & 15.86 & 16.67 & 30.91 & 20.43 & 100 \\
\hline average RECS & 20.55 & 27.41 & 27.16 & 20.64 & 11.79 & \\
\hline average PAYAS & 21.93 & 28.56 & 29.56 & 31.65 & 30.56 & \\
\hline
\end{tabular}




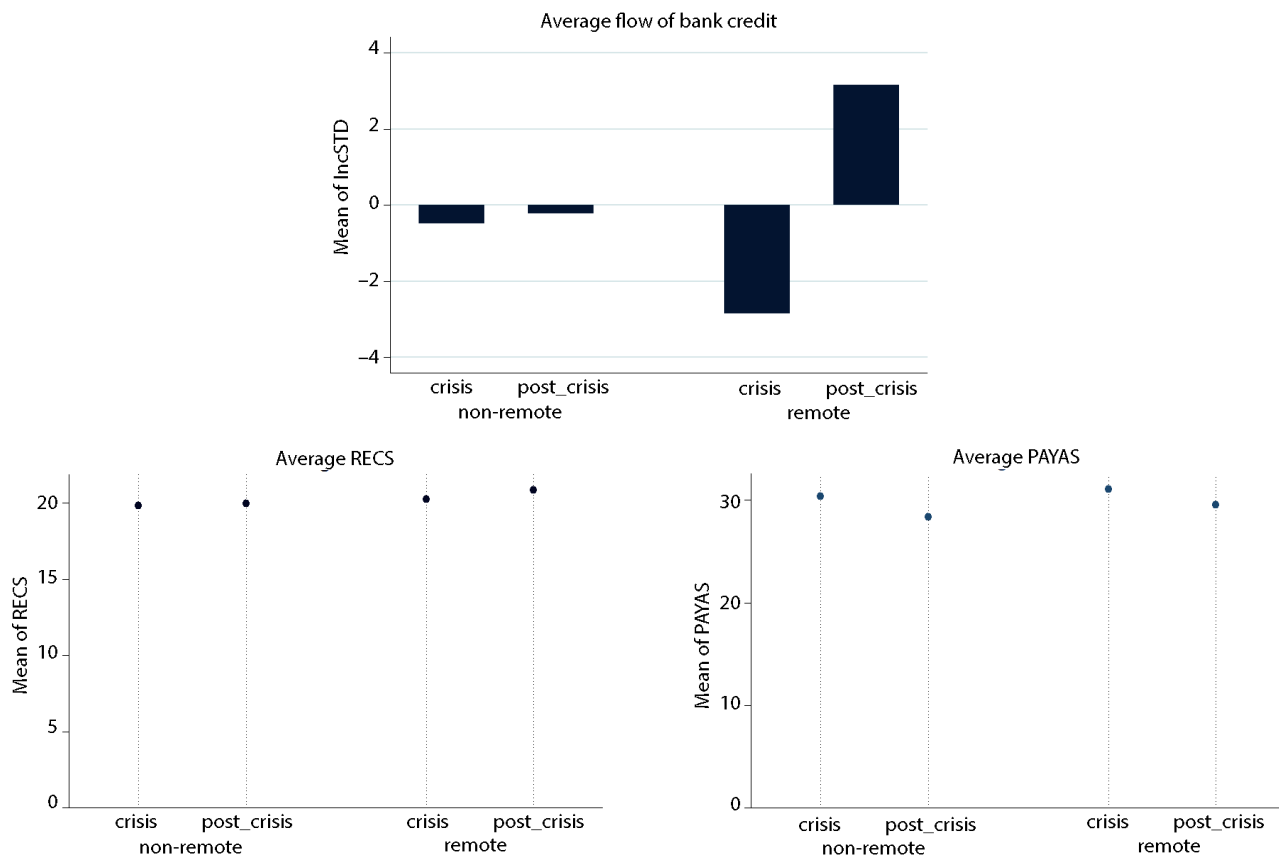

Figure 3. Flow of bank credit and trade credit: mean (in \%) during (2009-12) and after the crisis (2013-15)
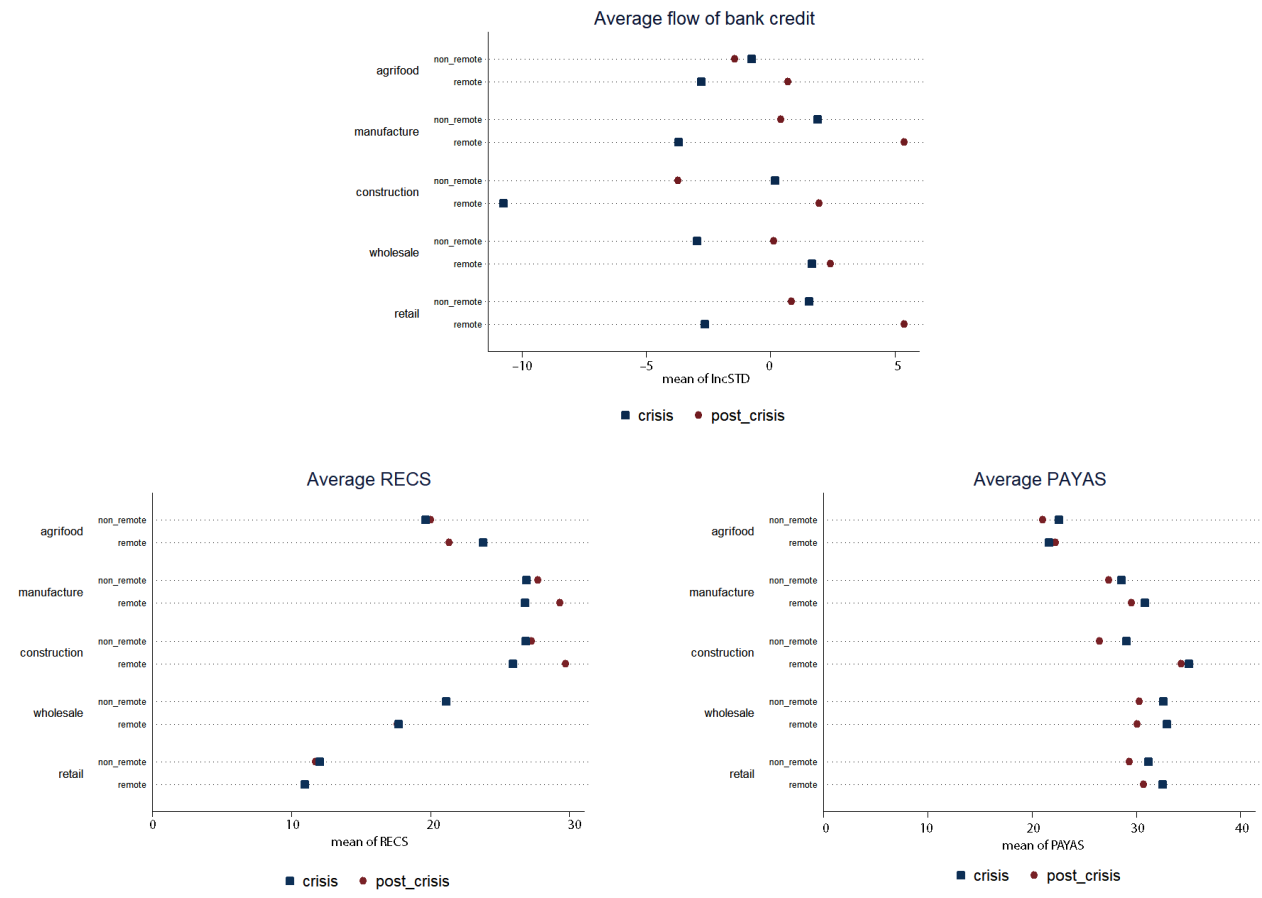

Figure 4. Credit measures by sector and rurality, during and after the crisis 
Sectors struggled by the crisis were construction (mostly), manufacture and retail trade in rural areas, and wholesale trade in urban and intermediate. Most sectors and areas saw a credit recovery after the crisis, particularly construction, manufacture and retail in rural areas. For RECS, the only difference in trade credit offered to customers is sectoral, while higher levels after the crisis in manufacture and construction in rural areas are also observed. For PAYAS, there is lower use of supplier financing after the crisis in most sectors and geographical areas. In terms of rurality, it is clear the higher financing via suppliers by rural construction firms.

\section{The impact of bank credit constraints over firms in rural areas}

The descriptive analysis provided some intuition that the hypothesis of a differential bank credit constraint for firms operating in rural areas is correct, while the effects in terms of net trade credit are not obvious. Hypothesis $\mathrm{H} 1$ is now tested using a difference-in-differences (DiD) approach that helps identify whether loanable funds shift back to credit constrained firms in rural areas after the crisis. The empirical specification is:

$$
\Delta \mathrm{STD}_{i t}=\gamma_{0}+\gamma_{1} D_{i}+\gamma_{2} T_{t}+\gamma_{3} D_{i} T_{t}+\omega_{i t},
$$

where subscript it refers to firm $i$ at time $t$. The flow in bank borrowing ( $\Delta \mathrm{STD}$ ) is compared in terms of a dummy variable $D_{i}$ that takes value equal to 1 for rural firms and 0 otherwise, and in terms of a dummy variable $T_{t}$ that takes values 0 during the credit crunch period (2009-2012) and 1 after the crisis. Finally, $\omega_{i t}$ is an error term.

The coefficient of interest is $\gamma_{3}$ : for $\mathrm{H} 1$ to hold it is required that $\gamma_{3}>0$ (with $\gamma_{3}>\gamma_{2}$ ). The results for the whole dataset (Table 3) show a $\gamma_{3}$ effect that is positive and statistically significant $(\mathrm{p}=0.017)$, and larger than $\gamma_{2}$. Moreover, the impact of being rural over the flow of bank credit is negative $\left(\gamma_{1}=-2.36\right)$, though statistically not significant. Testing by sector results in positive and significant evidence in manufacture, construction and retail.

Table 3. DiD test of hypothesis H1

\begin{tabular}{|l|c|c|c|l|c|c|c|}
\hline \multirow{2}{*}{} & \multicolumn{3}{|c|}{ Robust } & & \multicolumn{3}{c|}{ Robust } \\
\cline { 2 - 9 } & Coef. & Std.Err & $\mathrm{t}$ & & Coef. & Std.Err & $\mathrm{T}$ \\
\hline IncSTD & -2.36 & 1.632 & -1.45 & REMOTE & -10.93 & 4.710 & $-2.32^{* *}$ \\
\hline REMOTE & 0.26 & 1.039 & 0.25 & P2 & -3.91 & 3.318 & -1.18 \\
\hline P2 & 5.74 & 2.406 & $2.38^{* *}$ & DT & 16.60 & 5.752 & $2.89^{* * *}$ \\
\hline DT & \multicolumn{7}{|l|}{ Wholesale } \\
\hline Agrifood & -2.03 & 4.855 & -0.42 & REMOTE & 4.62 & 3.058 & 1.51 \\
\hline REMOTE & -0.69 & 3.609 & -0.19 & P2 & 3.08 & 1.876 & 1.64 \\
\hline P2 & 4.16 & 7.229 & 0.58 & DT & -2.34 & 4.846 & -0.48 \\
\hline DT & & & Retail & & \\
\hline Manufacture & -5.61 & 3.878 & -1.45 & REMOTE & -4.18 & 2.481 & -1.68 \\
\hline REMOTE & -1.50 & 2.829 & -0.53 & P2 & -0.71 & 1.511 & -0.47 \\
\hline P2 & 10.59 & 5.841 & 1.81 & DT & 8.72 & 3.834 & 2.28 \\
\hline DT
\end{tabular}




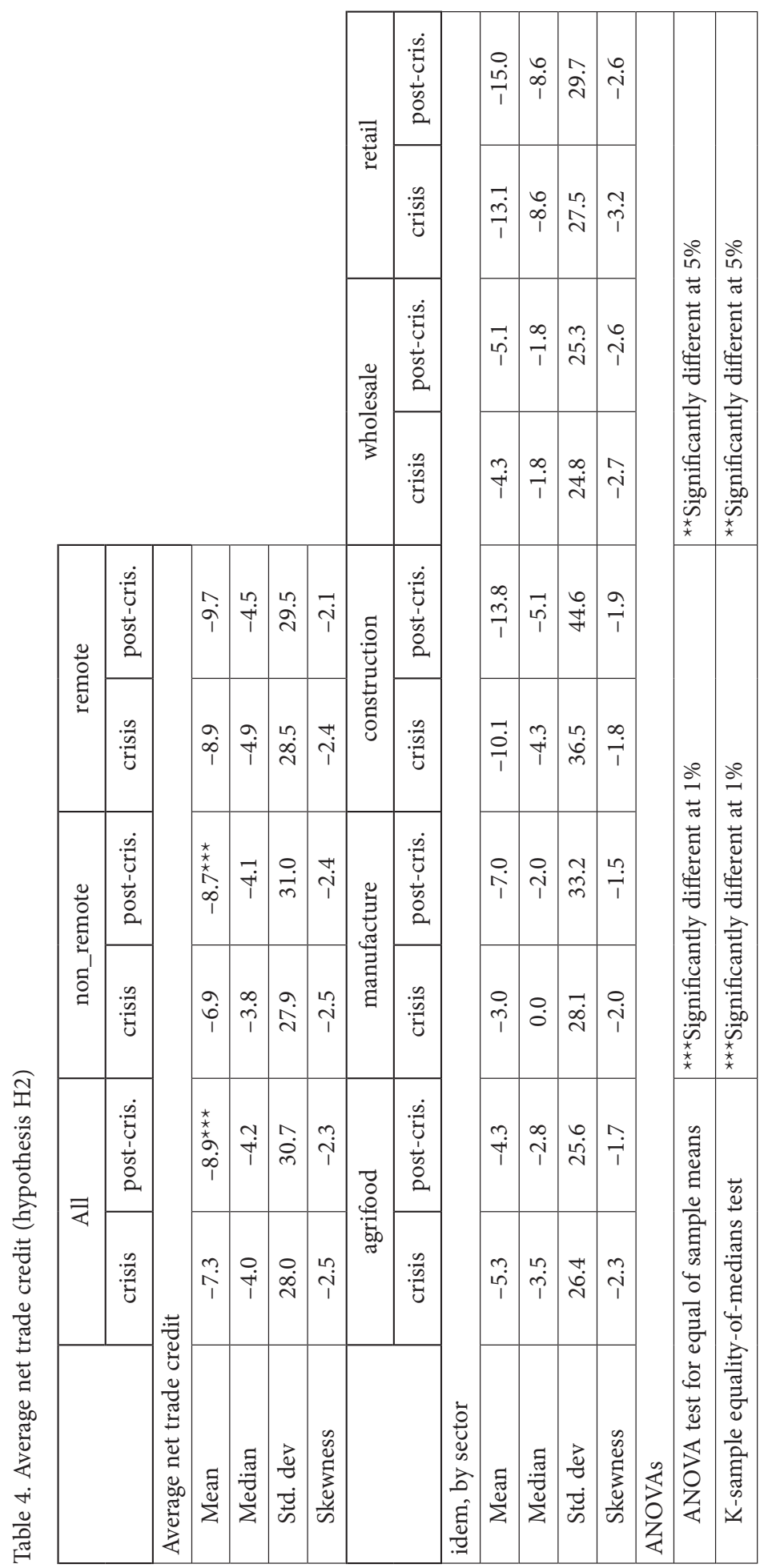


Next, the impact in terms of trade credit, during and after the crisis, is compared by measuring the net trade credit (NTCS) as the ratio of accounts receivable minus payables scaled by sales - here following McGuinness and Hogan (2016). The way hypothesis H2 is defined ("net trade credit is lower during the worse years of the banking crisis") implies that it must be tested whether NTCS values increased in the post-crisis years (2013-2015). Table 4 provides a summary of results. Net trade credit is negative overall and for any sectors. Companies run, on average, a negative working capital, with more sales financed by suppliers than financed to customers. This may be expected in retail-oriented industries - such as retail trade or construction, where figures are indeed more negative - but its pervasiveness across industries is remarkable: Galician firms have significantly sought to use trade payables to finance their activities, both during and after the banking crisis.

According to these results, NTCS values did not increase, generally speaking, after the worse years of the banking crisis. Mean values reduced anywhere except in agrifood, while ANOVA tests confirm that such decrease in net trade credit after the crisis is significant for the whole sample, and for firms outside rural areas. Median values, instead, are more stable. They only increased in agrifood, and rural areas. Thus, the increase in median values from -4.9 to -4.5 for rural areas is coherent with our intuition - despite a K-sample equality-ofmedians test suggests that it lacks of statistical significance. The different performance median vs. average suggests that "bad" debtor days deteriorated for some firms, pushing average figures down. This is confirmed by a negative skewness in all sectors and periods.

To sum up, the empirical evidence suggests firms used supplier financing to a large extent, but they continued to do so after the crisis. Nonetheless, the increase in median values for rural areas is coherent with the hypothesis.

We move on to test the causal effect of the firms' rural location over the flow of bank credit (hypothesis H3). The empirical specification is as follows:

$$
\Delta \mathrm{STD}_{i t}=\beta_{0}+\beta_{i} Z_{i t}+\delta_{t} P 2_{t}+\rho_{i} \text { REMOTE }_{i}+\gamma_{i t} R E M O T E_{i} \times P 2_{t}+\mu_{i}+\varepsilon_{i t},
$$

where subscript it refers to firm $i$ at time $t, Z_{i t}$ is a vector of control variables (determinants of capital structure) that includes FTA, ROA, SR, and AGE. REMOTE $i$ is a dummy variable equal to 1 if the SE operates in a remote rural municipality, as described in Section 3 and Figure 1 , and $P 2$ is a dummy variable equal to 1 for the post-crisis period. Finally, $\mu_{i}$ controls for the individual effects and $\varepsilon_{i t}$ is a random error.

For panel data models in which invariant regressors, such as REMOTE, are of particular interest, fixed effects estimator is not useful, as it uses data variation over time. ${ }^{2}$ When the Hausman test suggests that random effects estimation is neither a valid alternative, ${ }^{3}$ two solutions to obtaining estimations for invariant regressors are provided. The HT estimation method by Hausman and Taylor (1981) combines the fixed effects estimation with an IV estimation for the time-invariant regressors that are correlated with the individual effects.

\footnotetext{
2 Since the within estimator is obtained with the variables in differences with respect to the individual means, the coefficients of time-invariant regressors are not identified. The basic alternative is the random effects estimate, but this is conditioned to the assumption that the regressors are not correlated with the individual effects.

3 The value of the Hausman test obtained in the contrast between fixed effects and random effects was 24.65 with a P-value $=0.0004$. This leads to rejection of the null hypothesis that RE provides consistent estimates.
} 
The main criticism is that it requires an ex ante definition of a set of time-variant exogenous regressors (in a number equal to or greater than the number of time-invariant regressors to be tested) that are not correlated with the individual effects - since they act as instruments for the correlated invariant regressors. Some authors perform a Hausman test to compare the fixed effects and HT estimations, but this solution raises doubts since the contrast necessarily excludes time-invariant regressors. Consequently, the PZ method by Pesaran and Zhou (2018) is used for robustness. Suitable for models where $\mathrm{N}$ is large and $\mathrm{T}$ is small, it allows the estimation of invariant effects whether the invariant regressors are correlated with individual effects or not. The estimators are robust with heterokedasticity and autocorrelation. In order to apply HT to the model in Eq. (2), P2 and the interaction REMOTE ${ }^{\star} \mathrm{POST}$ are considered to be time-variant regressors that are not correlated with the individual effects. Table 5 summarizes the results under the two estimation methods.

Table 5. Testing the causal effect of rurality over the flow of bank credit

\begin{tabular}{|l|c|c|c|c|c|c|}
\hline \multirow{2}{*}{$\begin{array}{c}\text { Dependent variable: } \\
\Delta \text { STD }\end{array}$} & \multicolumn{3}{|c|}{$\begin{array}{c}\text { ESTIMATOR HT } \\
\text { (HAUSMAN-TAYLOR) }\end{array}$} & \multicolumn{3}{c|}{$\begin{array}{c}\text { ESTIMATOR FEF } \\
\text { (PESARAN-ZHOU) }\end{array}$} \\
\cline { 2 - 7 } & Coef & Std.Error & Z & Coef & Std.Error & T \\
\hline TV exogenous & & & & & & \\
\hline P2 & -3.438 & 2.374 & -1.45 & 3.179 & 2.428 & -1.31 \\
\hline REMOTE $\times$ POST & $\mathbf{5 . 2 5 6}$ & $\mathbf{2 . 6 5 1}$ & $\mathbf{1 . 9 8 ^ { * * }}$ & $\mathbf{5 . 4 5 2}$ & $\mathbf{2 . 8 2 3}$ & $\mathbf{1 . 9 3}^{* *}$ \\
\hline TV endogenous & & & & & & \\
\hline AGE & 0.876 & 0.588 & 1.49 & 0.851 & 0.591 & 1.44 \\
\hline FTA & -0.403 & 0.1001 & $-4.01^{* * *}$ & -0.404 & 0.1004 & $-4.02^{* * *}$ \\
\hline ROA & -0.567 & 0.1088 & $-5.21^{* * *}$ & -0.575 & 0.1096 & $-5.24^{* * *}$ \\
\hline SR & -0.001 & 0.0002 & $-3.65^{* * *}$ & -0.001 & 0.0002 & $-3.73^{* * *}$ \\
\hline TI exogenous & \multicolumn{7}{|c|}{} & & & & \\
\hline REMOTE & 0.917 & 2.013 & 0.46 & 0.489 & 2.112 & 0.23 \\
\hline cons & -3.266 & 10.832 & -0.30 & & & \\
\hline$N^{\circ}$ obs. & 11.972 & & & 11.972 & & \\
\hline Hausman test ${ }^{1}$ & \multicolumn{7}{|c|}{ Vs. Within Effects: $0.79(0.9978)$} & & & \\
\hline
\end{tabular}

Note: ${ }^{*}$ significant al $10 \%$; ${ }^{* *}$ significant at $5 \%$; ${ }^{* *}$ significant at $1 \%$. TV stands for "time variant", TI for "time invariant". Estimation Hausman-Taylor with robust estimate of variance-covariance matrix of the estimator.

${ }^{1} \chi$-stat and P-value, test de Hausman based on the difference between $\hat{\beta}_{H T}$ and $\hat{\beta}_{W}$. If $\mathrm{H}_{\mathrm{o}}$ is rejected, only the within estimator is consistent. Null hypothesis is accepted.

The effect REMOTE_POST (for firms in remote rural areas in the post-crisis period) is positive and statistically significant at $\mathrm{p}<0.05$. That is, the flow of bank credit improved 5,250 euros on average for firms in remote rural areas after the banking crisis. Control variables FTA and ROA show a negative and statistically significant relationship with the flow of bank credit, suggesting both a debt overhang situation, and a capital structure in line with POT theory (firms preferring internal to external financing, but also there may have been no operative debt inducing fiscal incentives, or credit was indeed unavailable). The impact 
of solvency (SR) is negative and statistically significant, against POT, with the implication that agency costs disincentived debt accumulation by credit constrained SMEs. The results are robust to alternative estimation models, HT and PZ. Moreover, a potential sectoral effect was tested - Table A2 in the SM - through a test of equality of coefficients between sectors, both in the $\mathrm{x}$-axis and the angular coefficients (control variables). There is no evidence to reject the hypothesis, so a differential sectoral effect is not justified.

Finally, the causality of bank credit over trade credit policies is tested. Two separate hypotheses, $\mathrm{H} 4 \mathrm{a}$ and $\mathrm{H} 4 \mathrm{~b}$, were defined, so two static panel data are used, for RECS and PAYAS, to test whether the impact on RECS for firms that had access to bank credit during the crisis is positive (i.e., firms with access to bank financing offered trade credit to their more constrained customers), and whether the impact on PAYAS for firms that were credit restricted during the crisis is negative (i.e., credit constrained firms sought to finance via suppliers). Hypotheses $\mathrm{H} 4 \mathrm{a}$ and $\mathrm{H} 4 \mathrm{~b}$ are defined in terms of the relationship of RECS and PAYAS with $\triangle$ STD. That means, on one hand, that no ex ante hypotheses are made regarding what "rurality" implies over RECS and PAYAS (the sign of the coefficient for REMOTE). On the other hand, it was confirmed above that rurality implies worse access to bank credit; now, we test whether this leads firms with credit restrictions to seek supplier financing - measured by $\triangle$ STD beta. The models for RECS and PAYAS are:

$$
\begin{gathered}
\text { RECS }_{i t}=\beta_{0}+\beta_{i} Z_{i t}+\delta_{i} \Delta \mathrm{STD}_{i t}+\gamma_{i} \text { REMOTE }_{i}+\mu_{i}+\varepsilon_{i t} \\
\text { PAYAS }_{i t}=\beta_{0}+\beta_{i} Z_{i t}+\delta_{i} \Delta \mathrm{STD}_{i t}+\gamma_{i} \text { REMOTE }_{i}+\mu_{i}+\varepsilon_{i t}
\end{gathered}
$$

where $Z_{i t}$ is a vector of regressors that follows the literature on the determinants of trade credit, subscript it refers to firm $i$ at time $t$, and where coefficients $\delta_{\text {it }}$ for $\Delta S T D_{i t}$ and $\gamma_{\mathrm{i}}$ for REMOTE are the bank credit and rural effects to be tested, respectively. Moreover, $\boldsymbol{\mu}_{i}$ controls for the individual effects of an unobservable nature, and $\boldsymbol{\varepsilon}_{i t}$ is a random error. The regressors and the expected impact over the dependent variable were described in Section 2, and they are listed next. $\mathrm{AGE}^{2}$ is included to moderate the effect of higher values of the variable. For RECS, the model includes $\operatorname{lnASSETS}(+), \operatorname{AGE}(+), \operatorname{AGE}^{2}, \operatorname{INTFINA}(+), \operatorname{PGROWTH}(+/-)$, NGROWTH(+/-), TURN(-), and STFINS(+). For PAYAS, we control for $\operatorname{lnASSETS}(-)$, AGE(-), AGE ${ }^{2}$, INTFINS(-), PGROWTH(+), NGROWTH(+), STDA(-), LEVER(-), and CURRAS(+). In both equations, P2 and the interaction REMOTE ${ }^{\star} \mathrm{POST}$ are introduced to be time-variant regressors not correlated with individual effects. They allow to have enough uncorrelated regressors to perform a HT regression.

Both models were estimated considering fixed effects - confirmed by the Hausman test. Consequently, following the same reasoning as in the previous model, the presence of timeinvariant regressors leads us to choose the HT and PZ models. Table 6 summarizes the main results. In order to apply HT to models in Eqs. (3) and (4), AGE and $\mathrm{AGE}^{2}$ are considered to be time-variant regressors not correlated with the individual effects.

Three are the most relevant results. First, there is significant evidence in favour of both hypotheses: firms with better access to bank credit increase the volume of trade receivables offered to customers (complementary hypothesis), while credit restricted firms seek more supplier financing (substitution hypothesis). Nonetheless, the impact is moderate: an increase 
Table 6. Testing the complementary and substitution hypotheses

\begin{tabular}{|c|c|c|c|c|c|c|}
\hline \multirow{2}{*}{$\begin{array}{c}\text { Dependent } \\
\text { variable: RECS }\end{array}$} & \multicolumn{3}{|c|}{ ESTIMATOR HT TAYLOR) } & \multicolumn{3}{|c|}{ ESTIMATOR FEF (PZ) } \\
\hline & Coef & Std.Error & $\mathrm{Z}$ & Coef & Std.Error & $\mathrm{T}$ \\
\hline \multicolumn{4}{|l|}{ TV exogenous } & \multicolumn{3}{|c|}{ TV } \\
\hline P2 & 0.246 & 0.316 & 0.78 & 0.296 & 0.315 & 0.94 \\
\hline REMOTE*POST & -0.086 & 0.650 & -0.13 & -0.113 & 0.6497 & -0.17 \\
\hline \multicolumn{7}{|l|}{ TV endogenous } \\
\hline$\Delta$ STD & 0.0052 & 0.0017 & $3.05^{* * *}$ & 0.0052 & 0.0017 & $3.06^{* * *}$ \\
\hline AGE & 0.0335 & 0.2024 & 0.17 & 0.0416 & 0.2026 & 0.21 \\
\hline AGEsq & -0.0016 & 0.0051 & -0.30 & -0.0020 & 0.0051 & -0.40 \\
\hline LnASSETS & 10.175 & 1.1441 & $8.89^{* * *}$ & 10.197 & 1.1432 & $8.92^{* * *}$ \\
\hline INTFINA & -0.1210 & 0.0262 & $-4.62^{\star * *}$ & -0.1213 & 0.0262 & $-4.63^{\star * *}$ \\
\hline PGROWTH & -0.0320 & 0.0112 & $-2.86^{\star * *}$ & -0.0322 & 0.0112 & $-2.88^{* * *}$ \\
\hline NGROWTH & -0.0807 & 0.0138 & $-5.83^{\star * *}$ & -0.0804 & 0.0138 & $-5.80^{* * *}$ \\
\hline TURN & 1.1146 & 0.1613 & $6.91^{* * *}$ & 1.1132 & 0.1612 & $6.91^{* * *}$ \\
\hline STFINS & 0.0946 & 0.0117 & $8.07^{* * *}$ & 0.0943 & 0.0117 & $8.06^{* * *}$ \\
\hline \multicolumn{4}{|l|}{ TI exogenous } & \multicolumn{3}{|c|}{ TI } \\
\hline REMOTE & 1.6879 & 1.0666 & $1.58^{1}$ & 1.806 & 1.154 & 1.57 \\
\hline _cons & -51.296 & 7.358 & -6.97 & & & \\
\hline No obs. & \multicolumn{6}{|c|}{12920} \\
\hline Hausman test ${ }^{2}$ & \multicolumn{3}{|c|}{ Vs. Within Effects: 1.62 (0.999) } & & & \\
\hline
\end{tabular}

Note: ${ }^{*}$ significant at $10 \%$; ${ }^{* *}$ significant at $5 \%$; ${ }^{* *}$ significant at $1 \%$. TV stands for "time variant", TI for "time invariant". Estimation Hausman-Taylor with robust estimate of variance-covariance matrix of the estimator. Hausman test fixed vs. random effects: $\mathrm{H}=428$, Prob $>$ chi $2=0.0000$. The null hypothesis is rejected, then the random estimator is inconsistent.

${ }^{1} \mathrm{p}=0.114 .^{2} \chi$-stat and P-value, Hausman test based on the difference between $\hat{\beta}_{H T}$ and $\hat{\beta}_{W}$. If $\mathrm{H}_{\mathrm{o}}$ is rejected, only the within estimator is consistent. The $\mathrm{df}()$ would be determined by the overidentifying restrictions in the Hausman-Taylor estimation. The null hypothesis is accepted.

\begin{tabular}{|l|c|c|c|c|c|c|}
\hline \multirow{2}{*}{$\begin{array}{c}\text { Dependent variable: } \\
\text { PAYAS }\end{array}$} & \multicolumn{3}{|c|}{ ESTIMATOR HT } & \multicolumn{3}{c|}{ ESTIMATOR FEF (PZ) } \\
\cline { 2 - 7 } & Coef & Std.Error & Z & Coef & Std.Error & T \\
\hline TV exogenous & 1.240 & 0.2315 & $5.36^{* * *}$ & 1.255 & 0.2310 & $5.44^{* * *}$ \\
\hline P2 & -0.319 & 0.5470 & -0.58 & -0.308 & 0.5473 & -0.56 \\
\hline REMOTE*POST & -0.0034 & 0.0014 & $-2.41^{* *}$ & -0.0034 & 0.0014 & $-2.41^{* *}$ \\
\hline TV endogenous & -1.657 & 0.1896 & $-8.74^{* * *}$ & -1.655 & 0.1908 & $-8.72^{* * *}$ \\
\hline$\Delta$ STD & 0.0127 & 0.0048 & $2.66^{* * *}$ & 0.0125 & 0.0048 & $2.61^{* * *}$ \\
\hline AGE & 9.617 & 0.9969 & $9.65^{* * *}$ & 9.618 & 0.9965 & $9.65^{* * *}$ \\
\hline AGEsq & -0.242 & 0.0217 & $-11.14^{* * *}$ & -0.242 & 0.0217 & $-11.15^{* * *}$ \\
\hline lnASSETS & 0.0302 & 0.0063 & $4.84^{* * *}$ & 0.0302 & 0.0062 & $4.84^{* * *}$ \\
\hline INTFINS
\end{tabular}


End of Table 6

\begin{tabular}{|c|c|c|c|c|c|c|}
\hline \multirow{2}{*}{$\begin{array}{c}\text { Dependent variable: } \\
\text { PAYAS }\end{array}$} & \multicolumn{3}{|c|}{ ESTIMATOR HT } & \multicolumn{3}{|c|}{ ESTIMATOR FEF (PZ) } \\
\hline & Coef & Std.Error & $\mathrm{Z}$ & Coef & Std.Error & $\mathrm{T}$ \\
\hline NGROWTH & 0.0761 & 0.0080 & $9.55^{\star * \star}$ & 0.0762 & 0.0080 & $9.57^{\star * *}$ \\
\hline STDA & -0.374 & 0.0206 & $-18.11^{\star * *}$ & -0.374 & 0.0206 & $-18.12^{* * *}$ \\
\hline LEVER & -0.166 & 0.0137 & $-12.07^{\star * *}$ & -0.166 & 0.0137 & $-12.08^{\star * *}$ \\
\hline CURRAS & 0.120 & 0.0195 & $6.15^{\star \star \star}$ & 0.120 & 0.0195 & $6.14^{\star * *}$ \\
\hline \multicolumn{4}{|l|}{ TI exogenous } & \multicolumn{3}{|c|}{ TI } \\
\hline REMOTE & 1.8019 & 1.1528 & $1.56^{1}$ & 1.8373 & 1.1816 & 1.55 \\
\hline _cons & -4.185 & 5.7450 & -0.73 & & & \\
\hline No obs. & \multicolumn{6}{|c|}{13141} \\
\hline Hausman test $^{2}$ & \multicolumn{3}{|c|}{ Vs. Within Effects: 0.41 (0.999) } & & & \\
\hline
\end{tabular}

Note: ${ }^{\star}$ significant at $10 \% ;{ }^{* *}$ significant at $5 \% ;{ }^{* *}$ significant at $1 \%$. TV stands for "time variant", TI for "time invariant". Estimation Hausman-Taylor with robust estimate of variance-covariance matrix of the estimator. Hausman test fixed vs random effects: $H=685$, Prob $>$ chi $2=0.0000$. The null hypothesis is rejected, then the random estimator is inconsistent.

${ }^{1} \mathrm{p}=0.118 .{ }^{2} \chi$-stat and P-value, Hausman test based on the difference between $\hat{\beta}_{H T}$ and $\hat{\beta}_{W}$. If $H_{o}$ is rejected, only the within estimator is consistent. The $\mathrm{df}()$ would be determined by the overidentifying restrictions in the Hausman-Taylor estimation. The null hypothesis is accepted.

(decrease) of 100,000 euros in bank credit lead to an increase of 0.52 percentage points $(0.34$ percentage points) in the ratio of receivables to sales (payables to assets).

Second, all control variables show a significant effect, and signs coherent with the most frequent results in the literature except STFINA for RECS and lnASSETS for PAYAS. In particular, the negative coefficients for PGROWTH and NGROWTH in the equation for trade receivables suggest firms use trade credit as a marketing mechanism to improve weak sales. Third, remoteness implies both more offering and use of trade credit, but the effects are only weakly significant ( $\mathrm{p} \approx 0.1$ both for RECS and PAYAS). The results are robust to alternative estimation models, HT and PZ. Also for robustness, a sectoral effect was tested - Table A3 in the SM: models were re-estimated to allow the relationship between RECS (PAYAS) and IncSTD to be different across sectors (through multiplicative sectoral dummies). There is no econometric evidence to reject that the angular coefficients of the sectored IncSTD variable are equal, so a differential sectoral effect is not justified.

Hence, firms in remote rural locations receive and extend more trade credit. This goes against Niskanen and Niskanen (2006)'s findings, but they used data prior to the financial crisis. In addition, there is evidence of the complementary hypothesis of trade credit, where firms with better access to bank credit extend more trade credit, consistent with most recent articles. There is also evidence of the substitution hypothesis: firms facing bank credit restrictions make greater use of trade credit, consistent as well with other results in Spain (e.g., Carbó-Valverde et al., 2016). Obtaining positive results for the two hypotheses is in line with the idea that both the complementary and substitution hypotheses may coexist (GarciaAppendini \& Montoriol-Garriga, 2013). Nonetheless, the evidence is moderate in both cases in quantitative terms, but robust to two alternative estimation models. 


\section{Conclusions}

SEs operating in rural areas often lack of sufficient access to capital. This article delved into the "weak funding" handicap of rural firms by using a dataset in Galicia, where the Spanish banking crisis hit particularly hard. The descriptive analysis shows that the credit shortage during the crisis and the recovery in the flow of bank credit afterwards were stronger for rural firms. However, no relevant differences in terms of trade credit are observed. Testing the differential flow of bank credit to rural firms, an average increase of 5,300 euros after the banking crisis is obtained. The results are akin to the flight-to-quality hypothesis, here specifically for rural SEs.

Some policy implications follow. Rural firms must be aware of their dependence from bank credit, which often leads them to be excluded from regular financing circuits in periods of distress. The digital transformation may be an opportunity for them to solve this uneven access to traditional financing sources, by making use of financing opportunities such as crowdlending and P2P marketplaces. It would be interesting to observe whether these new Fintech companies are contributing to financing rural SEs in more recent times. For governments, the evidence of financial exclusion by the banking sector would support affirmative action in favour of start-ups and other firms in rural areas, particularly in times of financial straits. Financing vehicles such as grants, soft loans, and guarantees might be used. Moreover, the excess trade financing capacity of some sectors in rural areas may be utilized in other industries. Still, governments must be aware of possible damaging effects: structural break in SE financing engendered by policy thrusts during the crisis may have been responsible for exacerbation of trade credit substitution at the end of the crisis.

The article contributes to a weakly studied area: the access to bank credit by SEs in rural areas of Europe, and a differential substitutive role of trade credit related to the rurality attribute of the firms. The results confirm authorities' and practitioners' concerns about weak access to capital being a major barrier for the creation and survival of SMEs, particularly in rural areas. Firms remain too dependent on bank credit, and when they lack access to it, the greater substitution effect of trade credit confirms a worse access to other alternative sources. Moreover, depending on trade credit financing from suppliers and restricting commercial credit to customers implies a loss of competitive position, more acute the greater the bargaining power of customers and suppliers.

The main limitation comes from data available: access to bank credit was measured by the short-term debt in the balance sheet at year-end. Besides, it cannot be observed whether firms are using early payment discount and what is the cost of using trade credit. Future studies should use surveys to obtain direct measures of credit availability and use of trade credit to confirm the results. In particular, to check whether the significant impact (an increase of $0.34 \%$ of trade credit financing for each 100 mil euros) of reduced credit may be attributable to additional factors. Likewise, the research uses financial data from years 2008 to 2015. Such range was required to test the impact of the bank crisis in Spain before and after 2012, and six years is fair enough for a panel data analysis with the use of alternative econometric methods and robustness tests performed. That makes the analysis relevant for today, but it is open to more contributions in the field. Indeed, in Spain, the restructuring process of the banking 
industry continues today (with the merge in 2020 of Bankia and CaixaBank becoming the largest national bank) and, globally, with the emerging academic interest about the impact of Fintech on financial inclusion.

\section{Funding}

This research has received the funding of $R \& D+i$ Program Oriented to Society's Challenges (Ref. PID2019-106273RB-I00), "Money in Transformation: Actors, Processes and Social Effects of Financial Innovation", from the Ministry of Science and Innovation (Spain).

\section{Disclosure statement}

The authors declare no competing financial, professional or personal interests from other parties.

\section{References}

Baños-Caballero, S., García-Teruel, P. J., \& Martínez-Solano, P. (2016). Financing of working capital requirement, financial flexibility and SME performance. Journal of Business Economics and Management, 17(6), 1189-1204. https://doi.org/10.3846/16111699.2015.1081272

Besser, T. L., \& Miller, N. J. (2013). Community matters: Successful entrepreneurship in remote rural US locations. International Journal of Entrepreneurship and Innovation, 14(1), 15-27. https://doi.org/10.5367/ijei.2013.0104

Carbó-Valverde, S., Rodríguez-Fernández, F., \& Udell, G. F. (2016). Trade credit, the financial crisis, and SME access to finance. Journal of Money, Credit and Banking, 48(1), 113-143. https://doi.org/10.1111/jmcb.12292

Cassia, L., \& Vismara, S. (2009). Firms' trade credit and the local level of development of the banking system in Europe. Investment Management and Financial Innovations, 6(4), 46-58.

Civelek, M., Ključnikov, A., Krištofík, P., \& Rozsa, Z. (2019). Barriers in financing microenterprises from the perspective of Czech and Slovak microentrepreneurs. Journal of Business Economics and Management, 20(2), 244-267. https://doi.org/10.3846/jbem.2019.8114

European Commission. (2016, September 5-6). The Cork 2.0 Declaration 2016. In Cork 2.0 European Conference on Rural Development. Cork, Ireland. http://ec.europa.eu/agriculture/events/rural-development-2016_en.htm

de Castro, E. R., \& Teixeira, E. C. (2012). Rural credit and agricultural supply in Brazil. Agricultural Economics, 43(3), 293-302. https://doi.org/10.1111/j.1574-0862.2012.00583.x

Del Gaudio, B. L., Porzio, C., \& Verdoliva, V. (2018). Trade credit, SMEs and short-run survivorship: what we know and what we would like to know. Qualitative Research in Financial Markets, 10(4), 346-362. https://doi.org/10.1108/QRFM-02-2018-0014

Deloof, M., \& La Rocca, M. (2014). Local financial development and the trade credit policy of Italian SMEs. Small Business Economics, 44, 905-924. https://doi.org/10.1007/s11187-014-9617-x

Deloof, M., La Rocca, M., \& Vanacker, T. (2019). Local banking development and the use of debt financing by new firms. Entrepreneurship: Theory and Practice, 43(6), 1250-1276.

https://doi.org/10.1177/1042258718783486 
Erjavec, E., \& Rickson, J. (2016, September 5-6). Identification of current role of innovation and knowledge policy in agriculture and rural development with brief reference to strengths and weaknesses. In Cork 2.0 Conference on Rural Development. Cork. https://ec.europa.eu/agriculture/ sites/agriculture/files/events/2016/rural-development/ws3-erjavec_en.pdf

Friedline, T., Naraharisetti, S., \& Weaver, A. (2020). Digital redlining: Poor rural communities' access to fintech and implications for financial inclusion. Journal of Poverty, 24(5-6), 517-541. https://doi.org/10.1080/10875549.2019.1695162

Garcia-Appendini, E., \& Montoriol-Garriga, J. (2013). Firms as liquidity providers: Evidence from the 2007-2008 financial crisis. Journal of Financial Economics, 109(1), 272-291. https://doi.org/10.1016/j.jfineco.2013.02.010

Gustafson, C. R. (2005). Rural small business trade credit: A paradox. Agricultural Finance Review, 65(1), 45-57. https://doi.org/10.1108/00214660580001166

Harris, M., \& Raviv, A. (1990). Capital structure and the informational role of debt. The Journal of Finance, 45(2), 321-349. https://doi.org/10.1111/j.1540-6261.1990.tb03693.x

Hausman, J., \& Taylor, W. (1981). Panel data and unobservable individual effects. Econometrica, 49(6), 1377-1398. https://doi.org/10.2307/1911406

Instituto de Crédito Oficial. (2014). Informe anual 2014. www.ico.es/web/ico/informe-anual

Instituto de Crédito Oficial. (2015). Informe anual 2015. www.ico.es/web/ico/informe-anual

Khanal, A. R., \& Omobitan, O. (2020). Rural finance, capital constrained small farms, and financial performance: findings from a primary survey. Journal of Agricultural and Applied Economics, 52(2), 288-307. https://doi.org/10.1017/aae.2019.45

Kohardinata, C., Suhardianto, N., \& Tjahjadi, B. (2020). Peer-to-peer lending platform: From substitution to complementary for rural banks. Business: Theory and Practice, 21(2), 713-722. https://doi.org/10.3846/btp.2020.12606

Martínez-Sola, C., García-Teruel, P. J., \& Martínez-Solano, P. (2017). SMEs access to finance and the value of supplier financing. Revista Espanola de Financiación y Contabilidad, 46(4), 455-483. https://doi.org/10.1080/02102412.2017.1345196

McGuinness, G., \& Hogan, T. (2016). Bank credit and trade credit: Evidence from SMEs over the financial crisis. International Small Business Journal, 34(4), 412-445. https://doi.org/10.1177/0266242614558314

Niskanen, J., \& Niskanen, M. (2006). The determinants of corporate trade credit policies in a bankdominated financial environment: The case of Finnish small firms. European Financial Management, 12(1), 81-102. https://doi.org/10.1111/j.1354-7798.2006.00311.x

OECD. (2012). A Joint OECD/G20 GPFI Special Event on SME Finance. 19 April 2012, OECD Headquarters, Paris. https://www.oecd.org/cfe/smes/50112013.pdf

OECD. (2018, February 22-23). Enhancing SME access to diversified financing instruments [Discussion paper]. SME Ministerial Conference, Mexico City. https://www.oecd.org/cfe/smes/ministerial/ documents/2018-SME-Ministerial-Conference-Plenary-Session-2.pdf

Palacín-Sánchez, M.-J., Canto-Cuevas, F.-J., \& di Pietro, F. (2019). Trade credit versus bank credit: A simultaneous analysis in European SMEs. Small Business Economics, 53(4), 1079-1096. https://doi.org/10.1007/s11187-018-0101-x

Pesaran, M. H., \& Zhou, Q. (2018). Estimation of time-invariant effects in static panel data models. Econometric Reviews, 37(10), 1137-1171. https://doi.org/10.1080/07474938.2016.1222225

Petersen, M. A., \& Rajan, R. G. (1997). Trade credit: Theories and evidence. Review of Financial Studies, 10(3), 661-691. https://doi.org/10.1093/rfs/10.3.661 
Psillaki, M., \& Daskalakis, N. (2009). Are the determinants of capital structure country or firm specific? Evidence from SMEs. Small Business Economics, 33(3), 319-329. https://doi.org/10.1007/s11187-008-9103-4

Psillaki, M., \& Eleftheriou, K. (2015). Trade credit, bank credit, and flight to quality: Evidence from French SMEs. Journal of Small Business Management, 53(4), 1219-1240. https://doi.org/10.1111/jsbm.12106

Schwartz, R. A. (1974). An economic model of trade credit. Journal of Financial and Quantitative and Financial Analysis, 9(4), 643-657. https://doi.org/10.2307/2329765

Scott, J. (1977). Bankruptcy, secured debt and optimal capital structure. Journal of Finance, 32(1), 1-19. https://doi.org/10.1111/j.1540-6261.1977.tb03237.x

Siddiqui, T. A., \& Siddiqui, K. I. (2020). FinTech in India: An analysis on impact of telecommunication on financial inclusion. Strategic Change, 29(3), 321-330. https://doi.org/10.1002/jsc.2331

Smith, J. K. (1987). Trade credit and informational asymmetry. Journal of Finance, 42(4), 863-872. https://doi.org/10.1111/j.1540-6261.1987.tb03916.x 